\title{
THE CONCEPT OF THE AMBIDEXTROUS ORGANIZATION: SYSTEMATIC LITERATURE REVIEW
}

\author{
Andrzej Lis*, Barbara Józefowicz**, Mateusz Tomanek**, \\ Patrycja Gulak-Lipka***
}

\begin{abstract}
Background. Organizational ambidexterity is listed among up-to-date concepts recommended for managers to cope with turbulence and multidimensionality of the business environment. The idea of combining both evolutionary and revolutionary organizational changes seems to be very attractive but challenging to implement. Although it has been widely discussed in the management-related literature for more than twenty years, it has not been explored thoroughly and it still remains an interesting topic for further research.
\end{abstract}

Research aims. The aim of the paper is to analyze the literature contribution to the development of the ambidextrous organization concept as well as to identify the key problems and trends in research output. The research process is oriented to responding to the following questions: (1) What are the key contributions of the literature in the field to the development of the concept? (2) What are the key research topics and trends in the field?

Methodology. Systematic literature survey is the applied methodology. The Scopus database is used as a source for the sampling process.

Key findings. The analysis points out the following main areas of research interest in the field: (1) ambidexterity and ambidextrous organization conceptualization, (2) organizational management context (including managers) where these assumptions are embedded and studied, (3) innovations, organizational learning processes and creativity, and (4) strategic management aspects.

Keywords: organizational ambidexterity, ambidextrous organization, systematic literature review.

\footnotetext{
* Nicolaus Copernicus University in Toruń. E-mail: andrzejlis@econ.umk.pl

** Nicolaus Copernicus University in Toruń. E-mail: barbara.jozefowicz@umk.pl

**** Nicolaus Copernicus University in Toruń. E-mail: mtomanek@umk.pl

***** Nicolaus Copernicus University in Torun. E-mail: pgl@umk.pl
} 


\section{INTRODUCTION}

Nowadays, change is considered to be the only constant in contemporary management. Organizations are expected to follow the change paradigm and implement both reactive and anticipatory changes. What is more, as observed by Tushman and O'Reilly III $(1996$, p. 8$)$ "[t]o remain successful over long periods, managers and organizations must be ambidextrous - able to implement both incremental and revolutionary change." Popularized in the 1990s, the idea of organizational ambidexterity has been attracting the attention of researchers for more than two decades. However, the concept-related literature has not been revised in a systematic way, so far. The search for the conjunction of phrases "ambidextrous organization" and "systematic literature review" in the titles, abstracts and keywords of publications indexed in the Scopus database brings only one item (Alcaide-Muñoz \& Gutierrez-Gutierrez, 2017) which in fact focuses on the relationship between Six Sigma and organizational ambidexterity. Therefore, conducting the systematic literature review of the studies on the concept of an ambidextrous organization seems to be a valuable contribution to the filling the research gap in the field.

The aim of the paper is to analyze the literature contribution to the development of the ambidextrous organization concept as well as to identify the key problems and trends in research output. The research process is oriented to responding to the following questions: (1) What are the key contributions of the literature in the field to the development of the concept? (2) What are the key research topics and trends in the field?

\section{THE IDEA OF ORGANIZATIONAL AMBIDEXTERITY}

As observed by Raisch and Birkinshaw (2008, p. 376) "[w]hereas Duncan (1976) was the first to use the term organizational ambidexterity, it is March's (1991) landmark article that has frequently been cited as the catalyst for the current interest in the concept." March postulated that organizations need both exploitation and exploration to make their organizational learning processes efficient and effective. Combining and balancing exploitation and exploration processes is the 
foundation of the idea of organizational ambidexterity which allows organizations to be creative and adaptable at the same time, while also run their businesses in a traditional and proven method (O'Reilly III \& Tushman, 2004).

The growing interest of scholars in the idea of organizational ambidexterity, observed in recent years, resulted in an amassed body of knowledge. The review of literature by Raisch and Birkinshaw (2008) points out five streams and contexts in research focused on organizational ambidexterity i.e.: organizational learning, technological innovation, organizational adaptation, strategic management and organizational design. Moreover, these authors develop a comprehensive framework describing the variety of research perspectives and approaches in the literature aimed at identifying intra-organizational antecedents of ambidexterity (i.e. structure, context and leadership), its external determinants (environmental dynamism and competitive dynamics), moderators (market orientation, resource endowment and firm scope) as well as performance outcome related to accounting, market and growth. Raisch, Birkinshaw, Probst, and Tushman (2009) discuss "central tensions" within the literature related to organizational ambidexterity. First of all, the focus is given to separating or integrating exploitation and exploration processes within organizational units. The second key question is whether ambidexterity occurs at the organizational or individual level. The third tension is about static or dynamic approach to analyzing ambidexterity. Finally, the difference is in addressing organizational exploitation and exploration processes internally or externally. Similarly, Zakrzewska-Bielawska (2016a, 2016b) indicates various dimensions and levels of analysis observed in organizational ambidexterity studies. Firstly, there is a distinction between sequential and simultaneous ambidexterity. Secondly, ambidexterity may be considered both at the organizational and individual level. Thirdly, organizations may achieve their abilities to manage exploitation and exploration processes through structural ambidexterity, contextual ambidexterity or leadership ambidexterity.

Ambidextrous organizations are able to manage organizational paradoxes and simultaneously achieve aims which seem be divergent or even contradictory such as e.g.: short-term survival and long-term growth, incremental and radical innovations or competition vs cooperation etc. (Luo \& Rui, 2009; Zakrzewska-Bielawska, 2016a). Nevertheless, developing ambidexterity considered as a dynamic capability 
requires intra-organizational changes and adaptations. As Tushman and O'Reilly III (1996, p. 24) claim the "[a]bility to simultaneously pursue both incremental and discontinuous innovation and change results from hosting multiple contradictory structures, processes, and cultures within the same firm." Summing up, we employ the operating definition describing ambidextrous organizations as those, "with built-in capabilities for efficiency, consistency and reliability on the one hand, and experimentation, improvisation and luck on the other" (Tushman \& O’Reilly III, 1999, p. 20).

\section{RESEARCH METHODOLOGY}

As highlighted by Webster and Watson (2002, p. xiii), "[a] review of prior, relevant literature is an essential feature of any academic project. An effective review creates a firm foundation for advancing knowledge. It facilitates theory development, closes areas where a plethora of research exists, and uncovers areas where research is needed." The methodology of systematic literature review was applied to achieve the aim of the paper i.e. to analyze the literature contribution to the concept as well as to identify the key problems and trends in research output. Systematic literature review is defined as "a systematic, explicit, [comprehensive (p. 17)] and reproducible method for identifying the existing body of completed and recorded work produced by researchers, scholars and practitioners" (Fink, 2005, p. 3; quoted after: Okoli \& Schabram, 2010). Employing the method of systematic literature review, contrary to traditional, narrative literature review, ensures the rigor of scientific research (cf. Czakon, 2014; Orłowska et al., 2017). Systematic literature review is determined by a research question and characterized by unambiguous research sampling. Its aim is to identify and assess relevant research works as well as to analyze their contents (Orłowska et al., 2017). As observed by Czakon (2011), the research sampling is a key feature of systematic literature review. The research sampling process consists of three steps: selecting databases, searching for keywords in order to identify bibliometric records used as data for further analysis and 'clearing' the sample i.e. excluding records not relevant for analysis.

The research process consisted of three stages. The work of Lis (2017) was used as a benchmark to design the research process and the paper 
structure. First of all, the research field was mapped with the use of the technique of keywords analysis, following Lis, Czerniachowicz and Wieczorek-Szymańska (2017) as a benchmark. Secondly, the abstracts of the publications were analyzed in order to point out the key contributions they made to the field. Thirdly, the analysis of full texts was applied to study the idea of organizational ambidexterity and to identify key research topics and trends in the field.

In order to select the research sample, the publications including the phrase "ambidextrous organization" in their titles were retrieved from the following databases: Scopus (Sco), Web of Science Core Collection (WoS), Business Source Complete (BSC), JSTOR, Science Direct (SciDir), EconLit and CAIRN. The sampling process was conducted in two stages: stage 1 was limited to papers retrieved from Scopus database as of 17 December 2017, stage 2 included all remaining databases and was completed on 04 March 2018. The search was limited to article titles to identify the most relevant pieces of work. Truncation technique (searching for the phrase "ambidextrous organi?ation") was applied to incorporate into the research sample the publications using both spelling standards of English (i.e. British and American English). If the search engine was not able to service truncation, both spelling standards were queried (i.e. "ambidextrous organization" and "ambidextrous organisation"). The sample was limited to research and conference papers, while interviews as well as book reviews and introductions were excluded. The papers included in the research sample used for systematic literature review are enumerated in Table 1.

As a result of the sampling process, there were identified 42 publications indexed in: Scopus (35 items), Web of Science (7), Business Source Complete (25), JSTOR (1) and Science Direct (1). No relevant records were found in EconLit and CAIRN databases. Due to its unavailability, one of papers (Jansen, 2008) was removed from the sample. Finally, the "Main Sample" consisted of 41 papers published between 1996 and 2017. The majority of research productivity within the sample has been observed in recent years. Two thirds of the papers have been published since 2010 .

The research sample shows bias toward English which is the language of 36 papers. All remaining works were written in Spanish (3), French (1) and Chinese (1). In regard to research methodology, the dominance of the qualitative approach is observed. In total, the sample comprises 26 case studies or papers presenting companies' experiences 
Table 1. Ambidextrous organization systematic literature review sample

\begin{tabular}{|c|c|c|c|c|c|c|}
\hline No. & Author(s) & Sco & WoS & $\mathrm{BSC}$ & JSTOR & SciDir \\
\hline 1. & Tushman \& O’Reilly III (1996) & $\mathrm{X}$ & - & $\mathrm{X}$ & $\mathrm{X}$ & - \\
\hline 2. & Tushman \& O’Reilly III (1999) & $\mathrm{X}$ & - & $\mathrm{X}$ & - & - \\
\hline 3. & Nobelius (2003) & $\mathrm{X}$ & - & - & - & - \\
\hline 4. & O’Reilly III \& Tushman (2004) & $\mathrm{X}$ & $\mathrm{X}$ & $\mathrm{X}$ & - & - \\
\hline 5. & Martinich (2005) & $\mathrm{X}$ & $\mathrm{X}$ & - & - & - \\
\hline 6. & Van Looy et al. (2005) & - & - & $\mathrm{X}$ & - & - \\
\hline 7. & Bicen (2007) & - & - & $\mathrm{X}$ & - & - \\
\hline 8. & Mahmoud-Jouini et al. (2007) & $\mathrm{X}$ & - & $\mathrm{X}$ & - & - \\
\hline 9. & Tay \& Lusch (2007) & $\mathrm{X}$ & - & - & - & - \\
\hline 10. & Jansen (2008) & $\mathrm{X}$ & - & - & - & - \\
\hline 11. & Mirow et al. (2008) & $\mathrm{X}$ & - & $\mathrm{X}$ & - & - \\
\hline 12. & Simon \& Tellier (2008) & $\mathrm{X}$ & - & $\mathrm{X}$ & - & - \\
\hline 13. & Güttel \& Konlechner (2009) & - & - & $\mathrm{X}$ & - & - \\
\hline 14. & Markides \& Chu (2009) & $\mathrm{X}$ & - & - & - & - \\
\hline 15. & Wang \& Jiang (2009) & $\mathrm{X}$ & - & $\mathrm{X}$ & - & - \\
\hline 16. & Devins \& Kähr (2010) & $\mathrm{X}$ & - & - & - & - \\
\hline 17. & Dover \& Dierk (2010) & $\mathrm{X}$ & - & $\mathrm{X}$ & - & - \\
\hline 18. & Sarkees et al. (2010) & $\mathrm{X}$ & - & $\mathrm{X}$ & - & - \\
\hline 19. & Cao et al. (2011) & $\mathrm{X}$ & $\mathrm{X}$ & - & - & - \\
\hline 20. & Tahar et al. (2011) & $\mathrm{X}$ & - & - & - & - \\
\hline 21. & Durisin \& Todorova (2012) & $\mathrm{X}$ & - & $\mathrm{X}$ & - & - \\
\hline 22. & Leybourne \& Sainter (2012) & $\mathrm{X}$ & $\mathrm{X}$ & $\mathrm{X}$ & - & - \\
\hline 23. & López Zapata et al. (2012) & $\mathrm{X}$ & - & $\mathrm{X}$ & - & - \\
\hline 24. & Raisch et al. (2012) & $\mathrm{X}$ & - & $\mathrm{X}$ & - & - \\
\hline 25. & Agostini et al. (2014) & - & $\mathrm{X}$ & - & - & - \\
\hline 26. & Jiang \& Kortmann (2014) & $\mathrm{X}$ & - & - & - & $\mathrm{X}$ \\
\hline 27. & Chebbi et al. (2015) & $\mathrm{X}$ & - & $\mathrm{X}$ & - & - \\
\hline 28. & Chen \& Kannan-Narasimhan (2015) & $\mathrm{X}$ & - & $\mathrm{X}$ & - & - \\
\hline 29. & Frederick (2015) & - & - & $\mathrm{X}$ & - & - \\
\hline 30. & Güttel et al. (2015) & $\mathrm{X}$ & - & - & - & - \\
\hline 31. & Maier (2015) & $\mathrm{X}$ & $\mathrm{X}$ & - & - & - \\
\hline 32. & Agostini et al. (2016) & $\mathrm{X}$ & $\mathrm{X}$ & $\mathrm{X}$ & - & - \\
\hline 33. & Campanella et al. (2016) & $\mathrm{X}$ & - & - & - & - \\
\hline 34. & Nayak \& Bhatnagar (2016) & - & - & $\mathrm{X}$ & - & - \\
\hline 35. & Parmentier \& Picq (2016) & $\mathrm{X}$ & - & $\mathrm{X}$ & - & - \\
\hline 36. & Sinha (2016) & $\mathrm{X}$ & - & $\mathrm{X}$ & - & - \\
\hline 37. & Vorbach et al. (2016) & $\mathrm{X}$ & - & - & - & - \\
\hline 38. & Weng (2016) & - & - & $\mathrm{X}$ & - & - \\
\hline 39. & Agostini et al. (2017) & $\mathrm{X}$ & - & - & - & - \\
\hline 40. & Fernández-Pérez de la Lastra et al. (2017) & $\mathrm{X}$ & - & $\mathrm{X}$ & - & - \\
\hline 41. & Mora Pabón (2017) & $\mathrm{X}$ & - & - & - & - \\
\hline 42. & Mora Pabón et al. (2017) & $\mathrm{X}$ & - & - & - & - \\
\hline
\end{tabular}

Source: own study. 
in organizational ambidexterity. Most of them (12) are case studies of European companies from such countries as: France, Germany, Italy, Austria and Sweden. Other papers study the cases of American (7) and Asian (6) ambidextrous organizations. Following 7 publications are literature reviews discussing theoretical approaches to the issue of ambidexterity. Only 8 articles present the findings from quantitative research based on conducted surveys, interviews or model testing.

Since reviewed literature discussed the topic of ambidextrous organizations on different examples it is quite challenging to point out an industry that benefits the most from this concept. However, knowing that exploration of the future that includes innovations is equally important as ability of the company to be successful at exploiting the present, it may suggest that the companies in the technology-based industries are most likely to adapt to the theory of an ambidextrous organisation. The other examples of industries that have been presented in the reviewed publications include: automotive industry, electric industry, manufacturing, food and nutrition industry, telecommunications, banking sector, mechanical industry, chemical and pharmaceutical as well as media.

The bulk of the Main Sample (35 items, 83\%) is made by publications indexed in Scopus database which we labeled as "Scopus Title Sample" and used for keywords analysis. Scopus Title sampling was completed on 17 December 2017. Due to a limited size of the samples based on search in paper titles, we extended the scope search covering papers including the phrase "ambidextrous organi?ation" in their titles, keywords and abstracts. The results of the query, labeled as 'Scopus Topic Sample' were applied to validate the findings from keywords analysis based on Scopus Title Sample. Scopus Topic sampling was conducted on 4 March 2018.

Summing up, the key assumptions of the sampling process and the characteristics of the samples are presented in Table 2. 
Table 2. Research sampling for systematic literature review on ambidextrous organization

\begin{tabular}{|c|c|c|c|c|c|}
\hline Samples & $\begin{array}{l}\text { Searched } \\
\text { databases }\end{array}$ & $\begin{array}{c}\text { Scope } \\
\text { of search }\end{array}$ & $\begin{array}{c}\text { Date } \\
\text { of search }\end{array}$ & Size & $\begin{array}{l}\text { Application in } \\
\text { research process }\end{array}$ \\
\hline \multirow[b]{2}{*}{$\begin{array}{l}\text { Main } \\
\text { Sample }\end{array}$} & Scopus & \multirow[b]{2}{*}{ Titles } & 17 Dec. 2017 & \multirow[b]{2}{*}{$42(41)$} & \multirow[b]{2}{*}{$\begin{array}{l}\text { Abstract and full } \\
\text { text analysis }\end{array}$} \\
\hline & $\begin{array}{l}\text { Web of Science } \\
\text { Business Source } \\
\text { Complete } \\
\text { JSTOR } \\
\text { Science Direct } \\
\text { EconLit } \\
\text { CAIRN }\end{array}$ & & 4 Mar. 2018 & & \\
\hline $\begin{array}{l}\text { Scopus } \\
\text { Title } \\
\text { Sample }\end{array}$ & Scopus & Titles & 17 Dec. 2017 & 35 & Keywords analysis \\
\hline $\begin{array}{l}\text { Scopus } \\
\text { Topic } \\
\text { Sample }\end{array}$ & Scopus & $\begin{array}{l}\text { Titles, } \\
\text { keywords, } \\
\text { abstracts }\end{array}$ & 4 Mar. 2018 & 112 & Keywords analysis \\
\hline
\end{tabular}

Source: own study.

\section{KEYWORDS ANALYSIS}

Taking into account the aforementioned findings, in order to map the field of research on the concept of an ambidextrous organizations, keywords included in research sample publications were grouped into clusters and analyzed (cf. Table 3). The keywords related to the following categories were excluded from analysis: research methods and approaches, geographical names and industrial contexts. While clustering keywords, various spelling forms as well singular and plural forms were combined together.

The analysis of Scopus Title Sample [N $=35]$ reveals that "ambidextrous organization" is the most often (12 times) enumerated keyword within the publications comprising the research sample. Nevertheless, when sorted and grouped by keywords affinities, the category labelled as "innovations and change management" is found to be the most numerous (29 indications). It is followed by the keywords clusters related to: "ambidexterity and ambidextrous organization" (28), "organization and its stakeholders" (27), "management" (18), "organizational learning and exploration/exploitation processes" (16) and "strategic management" (16). The remaining categories include: "managers and leaders" (8), "human resources management" (7), "creativity" (6), and "information management and technology" (6). 


\begin{tabular}{|c|c|c|c|c|c|}
\hline & Z & $\vec{\infty}$ & 18 & పే & $\stackrel{\mathscr{m}}{\mathfrak{H}}$ \\
\hline 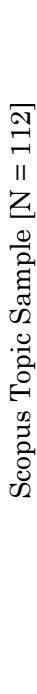 & 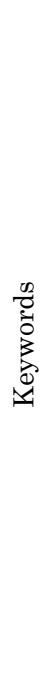 & 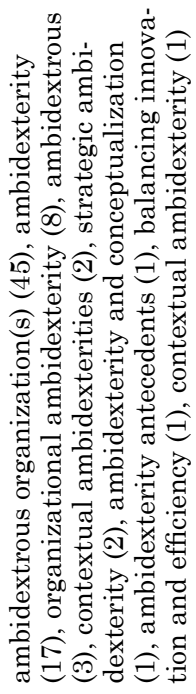 & 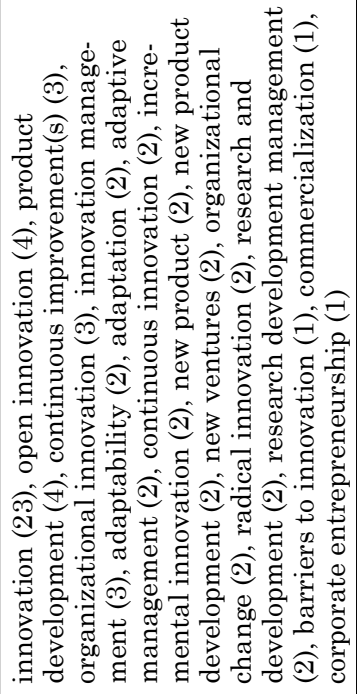 & 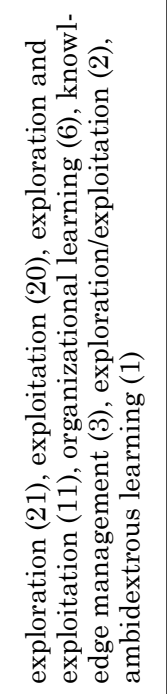 & 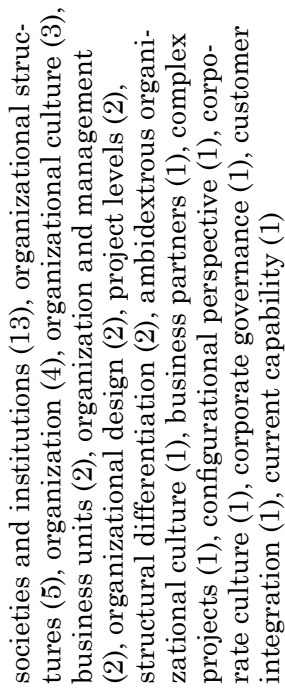 \\
\hline & Z & $\stackrel{\infty}{\sim}$ & 尺্ & $\stackrel{0}{-1}$ & ล \\
\hline 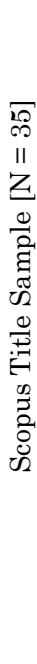 & 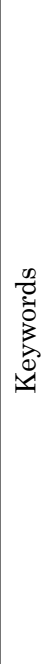 & 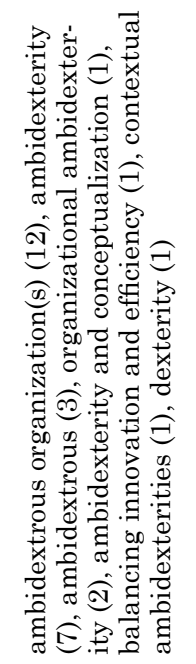 & 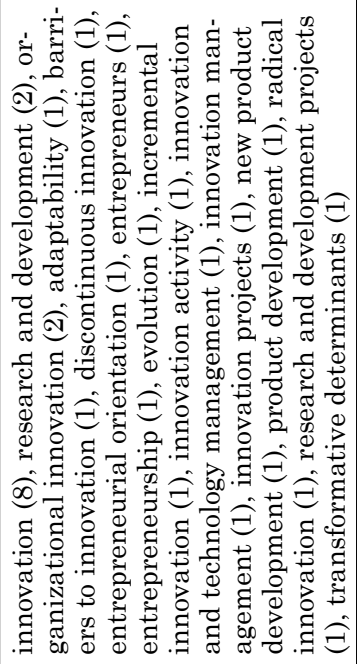 & 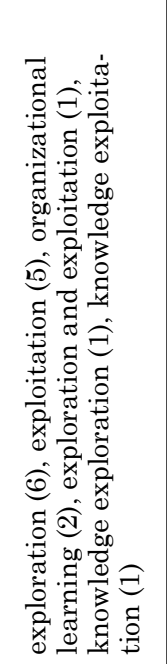 & 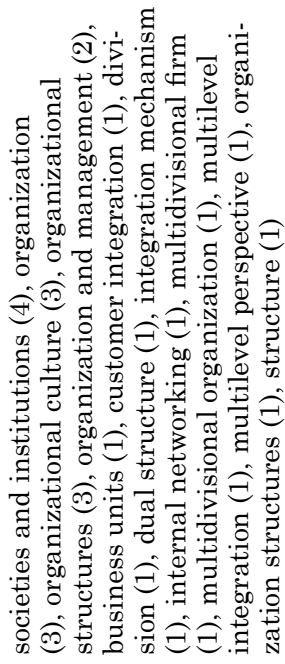 \\
\hline & & 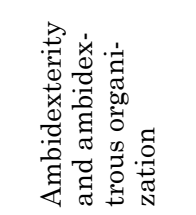 & 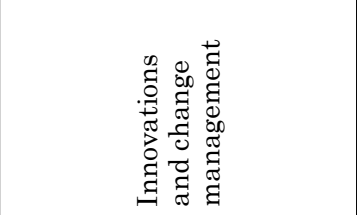 & 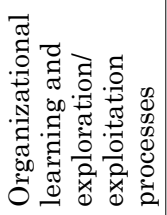 & 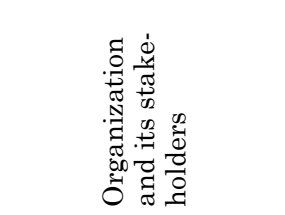 \\
\hline & 乙 & - & ง & $\dot{0}$ & $+\dot{ }$ \\
\hline
\end{tabular}




\begin{tabular}{|c|c|c|c|c|c|c|c|}
\hline & $\underline{Z}$ & ले & ๓ి & $\stackrel{\Omega}{\sim}$ & $\stackrel{ }{-}$ & $\infty$ & 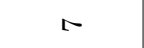 \\
\hline 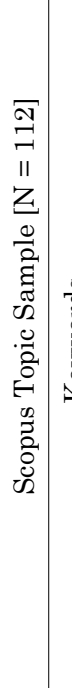 & 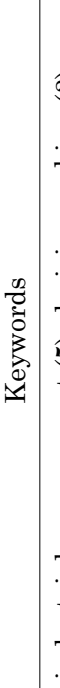 & 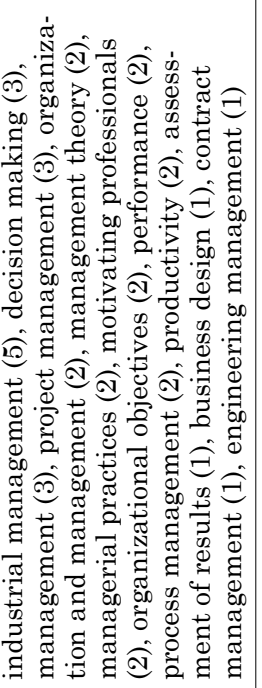 & 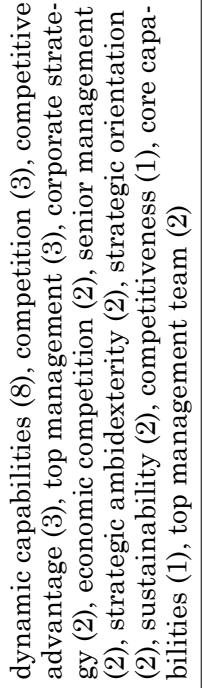 & 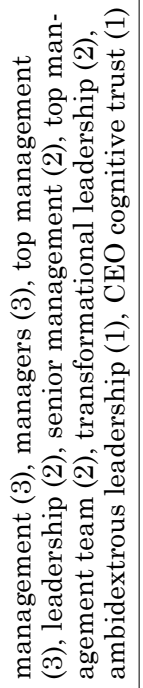 & 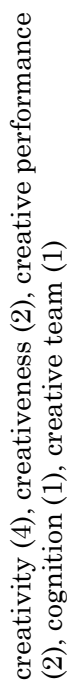 & 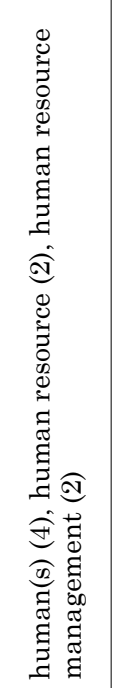 & 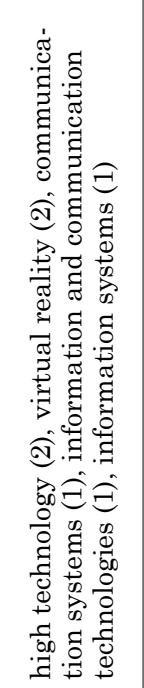 \\
\hline \multirow[b]{2}{*}{ 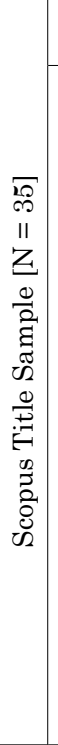 } & $\bar{Z}$ & $\stackrel{\infty}{\sim}$ & $\stackrel{\varphi}{\bullet}$ & $\infty$ & 0 & $\sim$ & 0 \\
\hline & 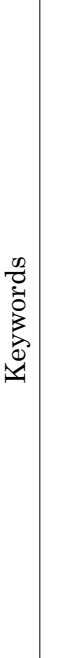 & 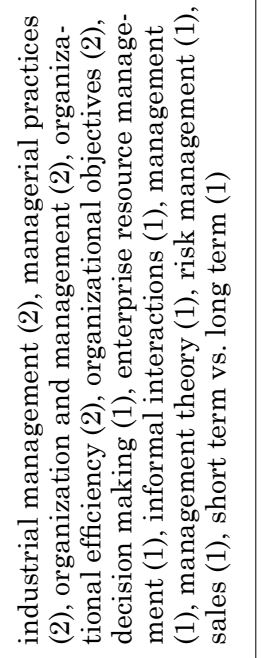 & 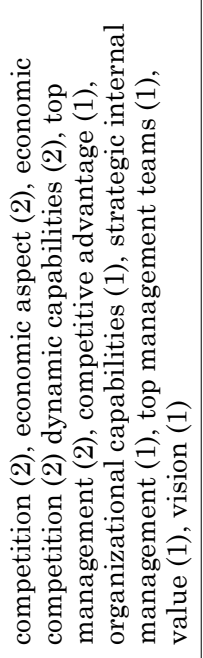 & 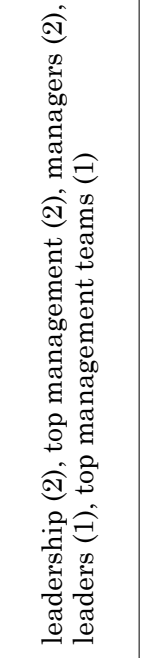 & 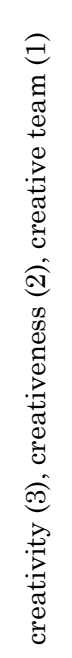 & 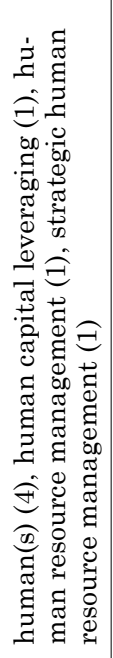 & 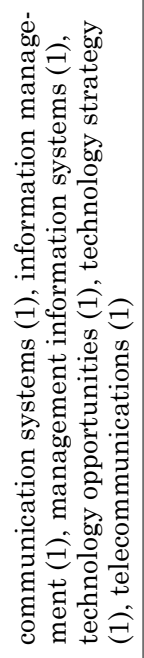 \\
\hline \multicolumn{2}{|c|}{ 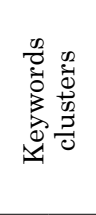 } & 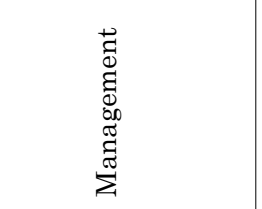 & 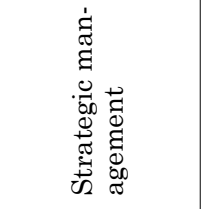 & 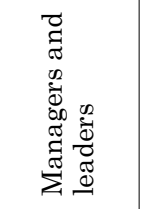 & 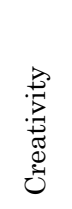 & 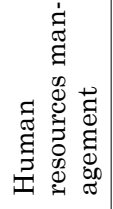 & 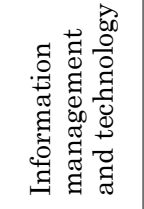 \\
\hline$\stackrel{\circ}{Z}$ & & $10^{\circ}$ & $0^{\circ}$ & $\stackrel{\circ}{\circ}$ & $\infty$ & $\dot{\sigma}$ & $\dot{-}$ \\
\hline
\end{tabular}


In Scopus Topic Sample [N = 112], again "ambidextrous organization" is the most often (45 times) mentioned keyword. However, a significant number of indications is reported also for "innovation" (23), "exploration" (21) and "exploitation" (20). While analyzing clusters of keywords, "ambidexterity and ambidextrous organization" is the most numerous category (81 indications). It is followed by clusters referring "innovations and change management" (65) and "organizational learning and exploration/exploitation processes" (64).

Summing up, the study of aforementioned keyword clusters points out four main areas of research interest in the field i.e. (1) ambidexterity and ambidextrous organization conceptualization, (2) organizational management context (including managers) where these assumptions are embedded and studied, (3) innovations, organizational learning processes and creativity, and (4) strategic management aspects.

\section{TOPIC ANALYSIS}

The next step of the study was the analysis of abstracts and complete texts of publications, which confirmed key research areas and trends in ambidextrous organization literature, identified through keywords analysis. The results of this part of investigation are presented in Table 4.

The first of the identified research areas refers to ambidexterity and ambidextrous organization conceptualization. Among eleven publications included in it, the following approaches can be distinguished: explanation of the ambidextrous organization idea and importance of organizational ambidexterity, ambidexterity as a multilevel construct and introducing the models of ambidextrous organization. The explanation of the ambidextrous organization idea and importance of organizational ambidexterity takes place in analysed papers mostly through discussing different cases of companies where innovations are crucial for competitive advantages, such as electronic technology (Tushman \& O'Reilly III, 1999) or, for instance, packaging, pharmaceuticals and telecoms industry (Maier, 2015). However, in the first category, one can find also theoretical considerations leading to formulation of a stipulative definition with established criteria enabling improvements in future research (Mora Pabón et al., 2017). Regarding the multilevel approach to the organizational ambidexterity 
Table 4. The key areas of research on the concept of an ambidextrous organization

\begin{tabular}{|c|c|c|}
\hline No. & Key research areas & Publications \\
\hline 1. & $\begin{array}{l}\text { Ambidexterity and ambidex- } \\
\text { trous organization conceptual- } \\
\text { ization }\end{array}$ & $\begin{array}{l}\text { Tushman \& O'Reilly III (1999) } \\
\text { Wang \& Jiang (2009) } \\
\text { López Zapata et al. (2012) } \\
\text { Raisch et al. (2012) } \\
\text { Chebbi et al. (2015) } \\
\text { Güttel et al. (2015) } \\
\text { Maier (2015) } \\
\text { Agostini et al. (2016) } \\
\text { Fernández-Pérez de la Lastra et al. (2017) } \\
\text { Mora Pabón et al. (2017) }\end{array}$ \\
\hline 2. & Organizational management & $\begin{array}{l}\text { Tushman \& O’Reilly III (1996) } \\
\text { Tushman \& O’Reilly III (1999) } \\
\text { Nobelius (2003) } \\
\text { O’Reilly III \& Tushman (2004) } \\
\text { Martinich (2005) } \\
\text { Mahmoud-Jouini et al. (2007) } \\
\text { Markides \& Chu (2009) } \\
\text { Güttel \& Konlechner (2009) } \\
\text { Devins \& Kähr (2010) } \\
\text { Dover \& Dierk (2010) } \\
\text { Cao \& Zhang (2011) } \\
\text { Tahar et al. (2011) } \\
\text { Durisin \& Todorova (2012) } \\
\text { Leybourne \& Sainter (2012) } \\
\text { Agostini et al. (2014) } \\
\text { Chen \& Kannan-Narasimhan (2015) } \\
\text { Maier (2015) } \\
\text { Frederick (2015) } \\
\text { Agostini et al. (2016) } \\
\text { Sinha (2016) } \\
\text { Parmentier \& Picq (2016) }\end{array}$ \\
\hline 3. & Innovation & $\begin{array}{l}\text { Simon \& Tellier (2008) } \\
\text { Mirow et al. (2008) } \\
\text { Jiang \& Kortmann (2014) } \\
\text { Weng (2016) } \\
\text { Nayak \& Bhatnagar (2016) } \\
\text { Agostini et al. (2017) } \\
\text { Mora Pabón (2017) }\end{array}$ \\
\hline 4. & Strategic management & $\begin{array}{l}\text { Van Looy et al. (2005) } \\
\text { Tay \& Lusch (2007) } \\
\text { Bicen (2007) } \\
\text { Sarkees et al. (2010) } \\
\text { Campanella et al. (2016) } \\
\text { Vorbach et al. (2016) }\end{array}$ \\
\hline
\end{tabular}

Source: own study. 
three papers represent it by paying attention to the role individual and team ambidexterity capabilities play in achieving the balance between exploration and exploitation. Using case study analysis, Wang and Jiang (2009) as well as Güttel et al. (2015) demonstrate that becoming an ambidextrous organization requires focusing not only on the whole company perspective, but also on lower levels of an organization - i.e. managers, teams and individual employees. The extension of this point of view is presented by Fernández-Pérez de la Lastra et al. (2017) in their proposal of a multilevel theoretical model of building ambidextrous organizations through intellectual capital. This paper connects the multilevel approach with the next noticeable common topic - introducing the models of an ambidextrous organization. Apart from the abovementioned model (Fernández-Pérez de la Lastra et al., 2017), there are four different integrative models of the ambidextrous organization. The first one, using comparative analysis of qualitative data gathered in semi-structured interviews, expresses the complex interaction between structural and behavioural context dimensions (Raisch et al., 2012). The second of proposed models, based on literature analysis, presents the integration of the different aspects of an organization which influence ambidexterity, and gives the beginning for further research (López Zapata et al., 2012). The third one, based on quantitative methods, demonstrates that an ambidextrous organization, represented as a higher-order construct according to second-order theoretical model, positively impacts innovation ambidexterity (Agostini et al., 2016). Whereas the forth one, called Provisional Evolutionary Model toward Multiunit Ambidextrous Organizations (Chebbi et al., 2015), reflects internal and external elements, and determinants of the transformational process in a comprehensive way, including theoretical and empirical research. Thus, the most often cited publications regarding ambidexterity and the ambidextrous organization conceptualization include the explanation of an idea and importance of these, describing ambidexterity as a multilevel construct and introducing the models of ambidextrous organization.

The second, and the largest category of key research topics - organizational management - contains publications which seem to have an important contribution to the knowledge on an ambidextrous organization, as well as to the business practice. Researchers make efforts to explain how to achieve success in combining opposing activities: 
exploitation and exploration to encourage innovations. Most of them, deliver practical recommendations for managers, based on different cases, for applying and maintaining the ambidextrous processes balancing innovation and efficiency (e.g. Tushman \& O'Reilly III, 1996; Cao \& Zhang, 2011; Maier, 2015; Sinha, 2016). For instance, Tahar, Niemeyer and Bouteiller (2011) convince that public institutions like universities could be ambidextrous organizations because they have to find a balance between enabling creativity and efficiency. Meanwhile Frederick (2015) demonstrates how to become an ambidextrous organization in seniors housing business. Parmentier and Picq (2016) investigate managing organizational ambidexterity in small videogame companies, as the representatives of SMEs in the creative industries. O'Reilly III and Tushman (2004), Martinich (2005), Dover and Dierk (2010) and Maier (2015) highlight the importance of managers' capabilities to guide building ambidextrous organization.

The majority of publications included into this research field represent structural ambidexterity - they concentrate on the separation from the rest of organization entrepreneurial units to create discontinuous innovation (Tushman \& O'Reilly III, 1999; Nobelius, 2003; MahmoudJouini et al., 2007; Devins \& Kähr, 2010; Chen \& Kannan-Narasimhan, 2015). Others reflect contextual ambidexterity approach emphasizing behavioral and social aspects enabling to combine exploration and exploitation in the one level of organization (Leybourne \& Sainter 2012; Parmentier \& Picq, 2016). Nevertheless, we can also find papers combining both structural and contextual approaches (Markides \& Chu, 2009; Güttel \& Konlechner, 2009; Durisin \& Todorova, 2012; Agostini et al., 2014; Agostini et al., 2016). Summarizing, in the set of papers concentrating on the organizational management context, the case study methodology dominates to explore, understand and recommend some successful elements of management processes aimed at becoming an ambidextrous organization.

The next distinguished key research area relates to "innovation", where authors applied a barriers approach to innovations to link them with different forms of organizational ambidexterity (Mirow et al., 2008) or investigate the social networks as an origin of a creative idea (Simon \& Tellier, 2008) as well as the source of ambidexterity in technological area (Weng, 2016). Moreover, several papers discuss the role of dynamic capabilities (Jiang \& Kortmann, 2014; Mora Pabón, 2017) or knowledge exploration and exploitation (Agostini et al., 2017) 
for innovation processes. Although one study found linkage between commitment based HR practices and knowledge creation in ambidextrous organizations (Nayak \& Bhatnagar, 2016). Thus, innovation is the topic with variety of research approaches.

"Strategic management" is the last among identified key research areas. In this field we can find interesting research comparing between focused and ambidextrous oriented firms' performance (Van Looy et al., 2005), but also the voice in discussion on resolving the exploration and exploitation paradox from strategic and marketing management point of view (Bicen, 2007). Moreover, researchers investigate the relationships between an ambidextrous organization and some other aspects, e.g. technology strategy (Vorbach et al., 2016), business performance in the banking sector (Campanella et al., 2016). They analyze the role the implementation of the marketing functional strategy plays in an ambidextrous approach and firm financial and non-financial performance (Sarkees et al., 2010); or they even test various competitive strategies in the virtual market of an ambidextrous organization (Tay \& Lusch, 2007).

\section{CONCLUSIONS}

Making attempts to identify the key study topics and trends observed in research output related to the concept of an ambidextrous organization, we have analyzed keywords and the contents of quality publications indexed in the Scopus database. The analysis points out the following main areas of research interest in the field: (1) ambidexterity and ambidextrous organization conceptualization, (2) organizational management context (including managers) where these assumptions are embedded and studied, (3) innovations, organizational learning processes and creativity, and (4) strategic management aspects.

While analyzing and interpreting the findings, the limitations of the research process should be made explicit. First of all, the methodology is limited to the systematic literature survey, while the quality and comprehensive mapping of the research field requires triangulation of research methods e.g. through descriptive bibliometric studies or co-citation analysis. Secondly, the research sampling process was confined to the Scopus database, which is naturally biased towards papers written in English, while neglecting valuable publications 
in other languages. Thirdly, some aspects of analysis e.g. clustering keywords are flawed with a high level of subjectivity. Therefore, the aforementioned gaps should be filled in further studies.

\section{REFERENCES}

Agostini, L., Filippini, R. \& Nosella, A. (2014). Ambidextrous organization and innovative performance: Testing the mediation of the internal networking. In: D. Carlucci, J.C. Spender, G. Schiuma (eds.), IFKAD 2014: $9^{\text {th }}$ International Forum on Knowledge Asset Dynamics: Knowledge and Management Models for Sustainable Growth (pp. 1764-1784), Retrieved from: http:// ualresearchonline.arts.ac.uk/7053/1/ProceedingsIFKAD2014_eBook.pdf (access: 6.03.2018).

Agostini, L., Nosella, A. \& Filippini, R. (2016). Towards an integrated view of the ambidextrous organization: A second-order factor model. Creativity and Innovation Management, 25(1), 129-141.

Agostini, L., Nosella, A. \& Filippini, R. (2017). Ambidextrous organization and knowledge exploration and exploitation: The mediating role of internal networking. International Journal of Business Innovation and Research, 14(1), 122-138.

Alcaide-Muñoz, C. \& Gutierrez-Gutierrez, L.J. (2017). Six Sigma and organizational ambidexterity: A systematic review and conceptual framework. International Journal of Lean Six Sigma, 8(4), 436-456.

Bicen, P. (2007). Balancing exploration and exploitation in innovation management: The role of strategic orientations in ambidextrous organizations. Society for Marketing Advances Proceedings, 92-93.

Campanella, F., Del Giudice, M., Thrassou, A., \& Vrontis, D. (2016). Ambidextrous organizations in the banking sector: An empirical verification of banks' performance and conceptual development. International Journal of Human Resource Management, 1-31 (paper in press).

Cao, X., Zhang, X. \& Xi, Y. (2011). Ambidextrous organization in harmony: A multi-case exploration of the value of He Xie management theory. Chinese Management Studies, 5(2), 146-163.

Chebbi, H., Yahiaoui, D., Vrontis, D. \& Thrassou, A. (2015). Building multiunit ambidextrous organizations: A transformative framework. Human Resource Management, 54, 155-177.

Chen, R.R. \& Kannan-Narasimhan, R.P. (2015). Formal integration archetypes in ambidextrous organizations. R\&D Management, 45(3), 267-286. 
Czakon, W. (2011). Metoda systematycznego przeglądu literatury. Przeglad Organizacji, 3, 57-62.

Czakon, W. (2014). Kryteria oceny rygoru metodologicznego badań w naukach o zarządzaniu. Organizacja i Kierowanie, 1(161), 51-62.

Duncan, R. (1976). The ambidextrous organization: Designing dual structures for innovation. In: R.H. Killman, L.R. Pondy \& D. Sleven (eds.), The Management of Organization (pp. 167-188). New York: North Holland.

Devins, G. \& Kähr, C.N. (2010). Structuring ambidextrous organizations: Exploitation and exploration as a key for long-term success. In: L. Stadtler, A. Schmitt, P. Klarner, Th. Straub (eds.), More than Bricks in the Wall: Organizational Perspectives for Sustainable Success (pp. 60-67). Wiesbaden: Gabler.

Dover, P.A. \& Dierk, U. (2010). The ambidextrous organization: Integrating managers, entrepreneurs and leaders. Journal of Business Strategy, 31(5), 49-58.

Durisin, B. \& Todorova, G. (2012). A study of the performativity of the ambidextrous organization theory: Neither lost in nor lost before translation. Journal of Product Innovation Management, 29, 53-75.

Fernández-Pérez de la Lastra, S., Garcia-Carbonell, N., Martín-Alcázar, F. \& Sánchez-Gardey, G. (2017). Building ambidextrous organizations through intellectual capital: A proposal. Intangible Capital, 13(3), 668-693.

Fink, A. (2005). Conducting Research Literature Reviews: From the Internet to Paper. Thousand Oaks: Sage Publications.

Frederick, R. (2015). Making innovation work: Ambidextrous organizations in the seniors housing and care industry. Seniors Housing \& Care Journal, 23(1), 76-84.

Güttel, W.H., Konlechner, S.W., \& Trede, J.K. (2015). Standardized individuality versus individualized standardization: The role of the context in structurally ambidextrous organizations. Review of Managerial Science, 9(2), 261-284.

Güttel, W.H. \& Konlechner, S.W. (2009). Continuously hanging by a thread: Managing contextually ambidextrous organizations. Schmalenbach Business Review, 61(2), 150-172.

Jansen, J.J.P. (2008). Combining competence building and leveraging: Managing paradoxes in ambidextrous organizations. Advances in Applied Business Strategy, 10, 99-119.

Jiang, R. \& Kortmann, S. (2014). On the importance of mediating dynamic capabilities for ambidextrous organizations. Procedia CIRP, 20(C), 85-92.

Leybourne, S.A. \& Sainter, P. (2012). Advancing project management: Authenticating the shift from process to 'nuanced' project-based management in the ambidextrous organization. Project Management Journal, 43(6), 5-15.

Lis, A. (2017). Relacyjny wymiar zdolności organizacji do absorpcji wiedzy zewnętrznej. Organizacja i Kierowanie, 2, 313-328. 
Lis, A., Czerniachowicz, B., \& Wieczorek-Szymańska, A. (2017). Leadership and corporate social responsibility: Topic research profiling. In: A. Nalepka, A. Ujwary-Gil (eds.), Business and Non-Profit Organizations Facing Increased Competition and Growing Customers' Demands (pp. 59-74). Nowy Sącz: Wyższa Szkoła Biznesu - National Louis University.

Luo, Y.D. \& Rui, H.C. (2009). An ambidexterity perspective toward multinational enterprises from emerging economies. Academy of Management Perspectives, 23(4), 49-70.

López Zapata, E., Garcia Muiña, F.E. \& Garcia Moreno, S.M. (2012). From the learning to the ambidextrous organization: Theoretical evolution of organizational learning. Cuadernos de Administracion, 25(45), 11-37.

Mahmoud-Jouini, S.B., Charue-Duboc, F. \& Fourcade, F. (2007). Multilevel integration of exploration units: Beyond the ambidextrous organization. In: G.T. Solomon (ed.), Academy of Management 2007 Annual Meeting Proceedings: August 3-8, 2007, Philadelphia: Doing Well by Doing Good. [Briarcliff Manor, N.Y.]: Academy of Management.

Maier, J. (2015). The Ambidextrous Organization: Exploring the New While Exploiting the Now. London: Palgrave Macmillan.

March, J.G. (1991). Exploration and exploitation in organizational learning. Organization Science, 2, 71-87.

Markides, C. \& Chu, W. (2009). Innovation through ambidexterity: How to achieve the ambidextrous organization? In: L.A. Costanzo, R.B. MacKay (eds.), Handbook of Research on Strategy and Foresight (pp. 324-342). Northampton: Elgar Publishing.

Martinich, L. (2005). Communicating the vision in an ambidextrous organization: Connecting with both sides of your brain. In: IEEE International Professional Communication Conference Proceedings (pp. 596-601).

Mirow, C., Hoelzle, K. \& Gemuenden, H.G. (2008). The ambidextrous organization in practice: Barriers to innovation within research and development. In: Academy of Management 2008 Annual Meeting: The Questions We Ask. Academy of Management.

Mora Pabón, R. (2017). The ambidextrous organization: Relationship and characteristics with longevity from the perspective of dynamic capabilities. Espacios, 38(39).

Mora Pabón, R., Grueso Hinestroza, M.P. \& Rodriguez Romero, C.A. (2017). Conceptualization of the ambidextrous organization: From the perspective of dynamic capabilities. Espacios, 38(34), 2.

Nayak, S. \& Bhatnagar, J. (2016). Impact of commitment based HR practices on knowledge creation in ambidextrous organizations. Academy of Management Annual Meeting Proceedings, 1. 
Nobelius, D. (2003). An ambidextrous organization in practice: Strategic actions in Ericsson's management of 'Bluetooth'. International Journal of Mobile Communications, 1(1-2), 57-90.

Okoli, C. \& Schabram, K. (2010). A guide to conducting systematic literature review of information systems research. Sprouts: Working Papers on Information Systems, 20(26). Retrieved from: http://sprouts.aisnet.org/10-26 (access: 4.03.2018).

O'Reilly III, C.A. \& Tushman, M.L. (2004). The ambidextrous organization. Harvard Business Review, 82(4), 74-81.

Orłowska, A., Mazur, Z. \& Łaguna, M. (2017). Systematyczny przegląd literatury: Na czym polega i czym się różni od innych przeglądów. Ogrody Nauk i Sztuk, 7, 350-363.

Parmentier, G. \& Picq, T. (2016). Managing creative teams in small ambidextrous organizations: The case of videogames. International Journal of Arts Management, 19(1), 16-30.

Raisch, S. \& Birkinshaw, J (2008). Organizational ambidexterity: Antecedents, outcomes and moderators. Journal of Management, 34(3), 375-409.

Raisch, S., Birkinshaw, J., Probst, G. \& Tushman, M.L. (2009). Organizational ambidexterity: Balancing exploitation and exploration for sustained performance. Organization Science, 20(4), 685-695.

Raisch, S., Zimmermann, A. \& Cardinal, L. (2012), A revised blueprint of the ambidextrous organization: Reuniting structural and contextual theories. In: Academy of Management 2012 Annual Meeting Conference Proceedings (pp. 1295-1300). Academy of Management.

Sarkees, M., Hulland, J., \& Prescott, J. (2010). Ambidextrous organizations and firm performance: The role of marketing function implementation. Journal of Strategic Marketing, 18(2), 165-184.

Simon, F. \& Tellier, A. (2008). Creativity and social networks in an ambidextrous organization. Revue Française de Gestion, 187(7), 145-159.

Sinha, S. (2016). Managing an ambidextrous organization: Balancing innovation and efficiency. Strategic Direction, 32(10), 35-37.

Tahar, S., Niemeyer, C., \& Bouteiller, R. (2011). Transferral of business management concepts to universities as ambidextrous organizations. Tertiary Education and Management, 17(4), 289-308.

Tay, N.S.P. \& Lusch, R.F. (2007). Agent-based modeling of ambidextrous organizations: Virtualizing competitive strategy. IEEE Intelligent Systems, 22(5), 50-57.

Tushman, M.L. \& O’Reilly III, C.A., (1996). Ambidextrous organizations: Managing evolutionary and revolutionary change. California Management Review, 38(4), 8-30. 
Tushman, M.L. \& O’Reilly III, C.A. (1999). Building ambidextrous organizations: Forming your own 'skunk works'. Health Forum Journal, 42(2), 20-23.

Van Looy, B., Martens, T., \& Debackere, K. (2005). Organizing for continuous innovation: On the sustainability of ambidextrous organizations. Creativity and Innovation Management, 14(3), 208-221.

Vorbach, S., Mueller, C., \& Egger, K. (2016). Technology strategies and ambidextrous organizations. In: L. Pretorius, G.A. Thopil \& Y. Hosni (eds.), LAMOT 2016 $25^{\text {th }}$ International Association for Management of Technology Conference Proceedings: Technology - Future Thinking 2016 (pp. 1430-1446), University of Pretoria.

Wang, F. \& Jiang, H. (2009). Innovation paradox and ambidextrous organization: A case study in development teams in air conditioner in Haier. Frontiers of Business Research in China, 3(2), 271-300.

Webster, J. \& Watson, R.T. (2002). Analyzing the past to prepare for the future: Writing a literature review. MIS Quarterly, 26(2), xiii-xxiii.

Weng, C.S. (2016). Vacillation between the exploitation and the exploration of technology: Ambidextrous organization. Journal of Management, 34(2), 189-214.

Zakrzewska-Bielawska, A. (2016a). Ambidextrous organization jako przykład przedsiębiorstwa inteligentnego. Studia i Prace Kolegium Zarzadzania i Finansów, 148, 161-174.

Zakrzewska-Bielawska, A. (2016b). Paradoks eksploatacji i eksploracji - ambidexterity w zarządzaniu strategicznym. Prace Naukowe Uniwersytetu Ekonomicznego we Wroctawiu, 420, 435-449.

Zakrzewska-Bielawska, A. (2017). Ambidextrity jako zdolność dynamiczna w odpowiedzi na niepewność otoczenia. Studia Oeconomica Posnaniensia, 5(9), 174-190. 


\section{KONCEPCJA ORGANIZACJI OBURĘCZNEJ: SYSTEMATYCZNY PRZEGLĄD LITERATURY}

Tło badań. „Oburęczność” organizacyjna zaliczana jest do najnowszych koncepcji zarządzania rekomendowanych $\mathrm{w}$ celu radzenia sobie $\mathrm{z}$ turbulencją i wielowymiarowością otoczenia organizacyjnego. Idea łączenia zmian organizacyjnych o charakterze ewolucyjnym i radyklanym wydaje się bardzo atrakcyjna, ale jednocześnie trudna do wdrożenia. Pomimo że koncepcja ta jest szeroko analizowana w literaturze przedmiotu z zakresu nauk o zarządzaniu od ponad 20 lat, w dalszym ciagu pozostaje interesujacym obszarem badań naukowych.

Cele badań. Celem artykułu jest analiza wkładu literatury przedmiotu w rozwój koncepcji organizacji oburęcznej (ambidexterous organization) oraz zidentyfikowanie kluczowych problemów i trendów badawczych. Proces badawczy został ukierunkowany na uzyskanie odpowiedzi na następujące pytania: (1) Jakie są najważniejsze publikacje naukowe, które przyczyniły się do rozwoju koncepcji organizacji oburęcznej? (2) Jakie sa kluczowe tematy i trendy w obrębie pola badawczego?

Metodyka. Do realizacji celu pracy zastosowano metodę systematycznego przeglądu literatury. Źródłem danych w procesie doboru próby badawczej była baza Scopus.

Kluczowe wnioski. Analiza słów kluczowych oraz treści abstraktów i artykułów zakwalifikowanych do próby badawczej wskazuje na cztery główne obszary zainteresowania w obrębie pola badawczego: (1) ideę i koncepcję oburęczności organizacyjnej, (2) kontekst organizacyjny i zarządzania, w którym badane sa założenia koncepcji, (3) innowacje, procesy organizacyjnego uczenia się i kreatywność oraz (4) zarządzanie strategiczne.

Słowa kluczowe: organizacyjna oburęczność, organizacja oburęczna, systematyczny przegląd literatury. 